\title{
Die atmosfeer in die erediens deur die loop van die geskiedenis
}

B J de Klerk en F W Leuschner

(Noordwes Universiteit)

\section{ABSTRACT}

\section{Atmosphere in the worship service through history}

The worship service occupies a central position in the life of the believer and therefore the atmosphere in the worship service is vital. The variations through history are studied in this article. The viewpoints of the first four centuries, the Middle Ages, Reformation, post-Reformation and twentieth century came under discussion. Lessons from history are stated. The atmosphere in the worship service should be such that the worshipper meets God with the necessary awe and respect. The service must also create an atmosphere of love, warmth, friendliness, and joy. All present must be invited and made welcome by the service. The atmosphere must further encourage and create room for everybody to participate and use their specific gifts. It can therefore change from service to service and within a single service. Important instruments in the atmosphere are the liturgical space, symbols, rituals, physical movement, gestures, music, song and the senses.

\section{INLEIDING}

In hierdie artikel word gefokus op die ontwikkeling van die erediens deur die geskiedenis van die kerk om te bepaal hoe die dimensies van atmosfeer in die erediens gefigureer het. Weens die beperkte omvang in ' $n$ artikel word breë lyne van die geskiedenis gevolg wat uiteindelik in ' $n$ aantal afgeleide beginsels uitmond. Die ondersoek word gedoen deur literatuurstudie van die tersaaklike inligting, wat dan deur kritiese denke evalueer word om uiteindelik tot sekere gevolgtrekkings te kom.

Die begrip “atmosfeer in die erediens” word in hierdie artikel as omvattend beskou (vgl. Schoeman 1994:183ev). Die erediens is die aangewese ruimte waar mense in hulle totaliteit kan handel (Vos en Pieterse 1997:9). In hierdie verband word daar gedink aan liggaamlike, geestelike en simboliese handelinge. Die geestelike kommunikasie kom tot die gelowige via die fisieke (of liggaamlike) taal van simbole, woorde, ritusse, handelinge en die totale atmosfeer van die situasie (Vos en Pieterse 1997:127). Dit beteken dat alle 
fisiese dinge in die kerk 'n rol speel, soos die argitektuur van die kerk, die sang en musiek, die rangskikking van die voorwerpe en simbole, en die verskillende handelende persone in die uitoefening van hul liturgiese funksies. Die reuk, die smaak, die weerkaatsing van brandgeskilderde vensters, die saamwees van die mense wat as familie of andersins kerk toe kom, die musiek, die sang - alles werk mee aan 'n belewenis van 'n ontmoeting met God (Müller 1990:23). Dit spreek alles tot die regterhemisfeer van die brein - dié deel wat meer beeldend en kreatief funksioneer en dalk in 'n meerdere mate in staat is om iets van God te verstaan as die meer logiese en analitiese kant van ons brein (Burger 1995:90).

Die volgende hoofperiodes kom onder die loep: 1) Die erediens in die tweede eeu na Christus, die tydperk net na die Nuwe Testament; 2) die vierde eeu waarin die kerk rykskerk geword het en die veranderinge in die erediens tydens die Middeleeue; 3) die tydperk van die Reformasie; 4) die invloed van die rasionalisme van die $19^{\mathrm{e}}$ en $20^{\mathrm{e}}$ eeue op die erediens; 5) die opkoms en invloed van die postmodernisme en; 6) die liturgiese beweging van die 20 ste eeu.

\section{DIE ATMOSFEER IN DIE EREDIENS VAN DIE TWEEDE EEU}

Vir die eerste tydperk na die Nuwe Testament is daar min duidelike gegewens oor die erediens, want die erediens en die inrigting daarvan was so as vanselfsprekend beskou en in die gemeentes só bekend, dat dit nie nodig geag is om dit te beskryf of te verduidelik nie (Wegman 1985:2). Tog is daar bronne wat inligting oor hierdie tydperk en die gestaltegewing van die erediens bied. Die hoofbronne is: die brief van Klemens van Rome aan die Korintiërs (95 na Christus); die sewe briewe van Ignatius van Antiogië (110-117 na Christus); die brief van Plinius, die goewerneur van Bitinië en Pontica, aan Keiser Trajanus (112 na Christus); die Didache ( \pm 100 of 150 na Christus); die tweede Klemensbrief (middel tweede eeu) en die apologie van Justinus die Martelaar (150 na Christus) (vergelyk Cabaniss 1989:11-22).

Die aspekte van die erediens in die Nuwe Testament, wat spore van beïnvloeding deur die Joodse sinagogediens vertoon, is in die vroeë kerk eenvoudig voortgesit (Patterson 1994:33). Die Christene het voortgegaan om die eredienste by te woon want dit is as die lewensaar van hulle geestelike lewe en van die gemeente ervaar. 
Hulle lof en aanbidding was gefokus op God, in ooreenstemming met die beginsels wat hulle uit die Ou Testament en beskikbare Nuwe-Testamentiese geskrifte kon verkry (Hurtado 1999:50). Volgens Justinus 1:65 het die erediens kortweg die samekoms of synaxis geheet. Waar die Jode daagliks in die tempel en by die huise bymekaar gekom het om te bid, weekliks vir Skriflesing (elke Sabbat in die sinagoge) en jaarliks vir die Paasmaal, het die Christene weekliks (Sondae) bymekaar gekom vir al drie elemente: (gemeenskaplike) gebed, Skriflesing (met uitleg) en die Nagmaal (Skarsaune 2002:379).

Uit Plinius se brief kan gesien word dat in die samekoms hulle eenheid bely is en dat almal onderneem het om aan Christus in alle omstandighede getrou te bly. Slegs daar en tydens die erediens kon ware koinonia beoefen word (Van Rooyen 1983:34). Die erediens is gekenmerk deur feesviering en was 'n vrolike geleentheid waarby al die aanbidders betrek is. Omdat Jesus Christus se dood en opstanding sentraal staan in hulle geloof, kom hulle op sy opstandingsdag bymekaar en vier hulle hierdie sentrale heilsfeite weekliks ook deur die Nagmaal. Die erediens vertoon duidelik twee brandpunte: die Woordverkondiging, met elemente daaromheen en die Nagmaalsviering, met elemente daaromheen (Webber 1982:49). McKinion (2001:43) wys op die belangrike plek van gebede, waar die gemeente vir mekaar en vir dié buite die gemeente gebid het. Die vredeskus het die oorgang aangedui van die Woorddiens na die Nagmaalsdiens (Wegman 1985:41-42). Die Nagmaal is aanvanklik gevier binne die raam van die liefdesmaaltyd, die agapé, en die koinonia soos dit in die Nuwe Testamentiese erediens tydens die Nagmaal bestaan het, is in die vroeë kerk net so oorgeneem. Die horisontale sowel as die vertikale koinonia is in die viering van die Nagmaal beoefen (Leuschner 2001:31). Die diepe eenheid tussen die gelowiges het so tot uiting gekom. Die benaming 'Eucharistie' (= danksegging) verwys na die bring van dank aan God deur die aanbidder vir sy verlossing deur Jesus Christus se dood (McKinion 2001:99). Waar die klem in die Joodse sinagoge op die leer geval het, het die erediens meer van 'n feesvierende karakter, wat ook in die atmosfeer na vore gekom het.

Van die ontstaan van die Christelike kerk het die gelowiges self 'n groot rol gespeel in die erediens en die deelname was meer korporatief as individualisties (Beukes 1993:50), want die doel van die erediens was om lewens te verander. Die groot klem op 
deelname en opregtheid is prysenswaardig en het belangrike implikasies vir die atmosfeer. In die erediens moet die atmosfeer opregte deelname bevorder en vreemdelinge en buitestanders moet in so 'n atmosfeer welkom en tuis voel.

Klemens van Aleksandrië was in die laat tweede eeu gekant teen die gebruik van musiekinstrumente in die erediens. Johannes Chrisostomos van Konstantinopel van die laat vierde eeu was dit hiermee eens (McKinion 2001:43). Klemens is van mening dat ' $n$ atmosfeer van luidrugtige feesvreugde in die kerk onaanvaarbaar is omdat dit emosies ontlok en deelnemers tot onvanpaste gedrag lei (sien die vertaling in McKinion 2001:47-48). Musiek lei, volgens Klemens, tot verleiding en 'n soeke na sensasie. Hoewel die klem op sang prysenswaardig is, is dit jammer dat die erediens reeds so vroeg as die tweede eeu op sekere plekke van emosie en belewenis gestroop is. Dit verskraal die atmosfeer in die erediens. Die mees algemene liggaamshouding vir sang en gebed was met uitgestrekte hande (Hughes 2004). Dit is gedoen terwyl gestaan is of gekniel is. In die Didache is dit opmerklik dat die gebed en danksegging vol lofprysings is, aangesien die erediens gesien is as 'n lofviering van die gemeente van God (Leonard 2004). Die gebruik van fisieke liggaamsuitinge en die klem op die feestelike karakter van die erediens moet aangeprys word.

\section{DIE KERK AS RYKSKERK EN DIE MIDDELEEUE}

Gedurende die eerste drie eeue na Jesus se geboorte was die Christelike kerk en die Christene die minderheid in die wêreld en is hulle dikwels misken en vervolg. Die kerk was grootliks gekant teen die destydse wêreldgees. Hierdie posisie van die kerk het ook aan die erediens 'n bepaalde vorm en inhoud gegee - die Christelike kerk was in die minderheid en was vreemdelinge in die wêreld (Wegman 1985:53). In die vierde eeu vind daar gebeurtenisse plaas wat die kerk, en daarmee ook die erediens, dramaties sou verander (Walker 1997:122-130). In 313 na Christus verleen Konstantyn en Licinius aan die Christene deur die Edik van Milaan die vryheid om te aanbid soos hulle wou. Verdere toegewings en groter voordele volg totdat die Christelike geloof, soos op die Konsilie van Nicea (325 na Christus) geformuleer, uiteindelik in 380 na Christus deur keiser Theodosius tot staatsgodsdiens verklaar word. Begryplik word die erediens deur hierdie situasie ingrypend verander. 


\subsection{Veranderinge in die erediens}

Tot op hierdie stadium het die kerk in huise bymekaargekom, maar nou dat die Christelike geloof die staatsgodsdiens geword het, stroom die massas na die erediens. Die bymekaarkomplekke was heeltemal ontoereikend en moes vergroot of nuut gebou word.

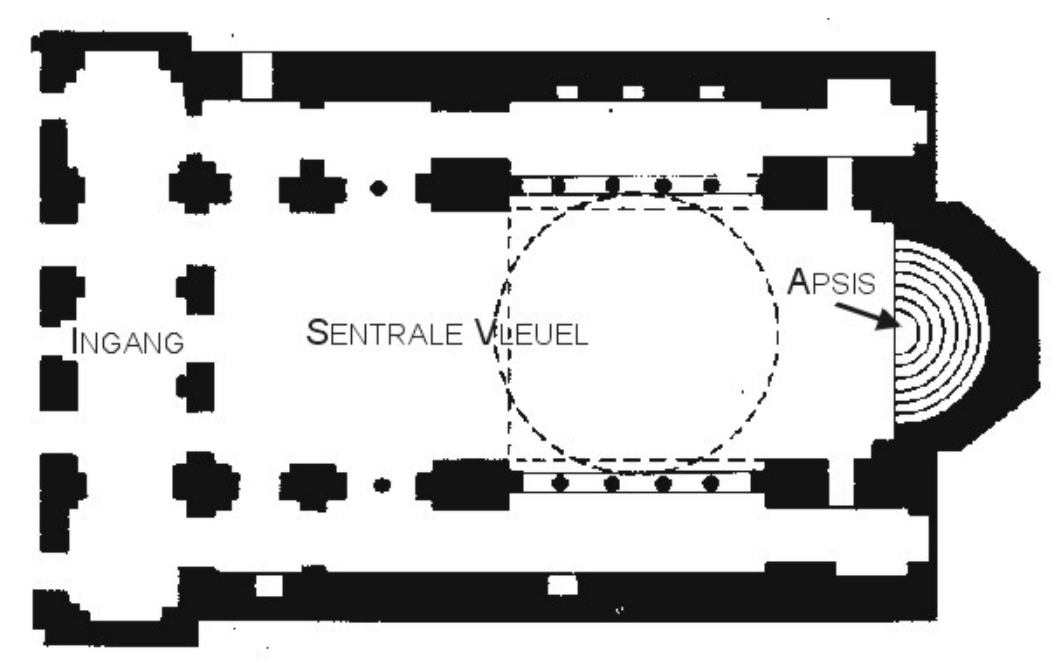

Sesde eeuse basiliek

(Cobb 1992:533)

Die kerk het die basiliek as vorm aangeneem, wat basies 'n sekulêre vorm van 'n vergadersaal was (Cobb 1992:529). Dit was 'n langwerpige gebou met ' $n$ apsis teenoor die ingangsdeure en drie vleuels, waarvan die middelste vleuel gewoonlik 'n hoër dak gehad het.

Die erediens verander van 'n geheime private byeenkoms na 'n openlike openbare byeenkoms. Die geboue van die staatsgodsdiens en die godsdiens van die regeerders moes indrukwekkend en weelderig wees. Daarom was daar ook finansiële steun vir die bou van groot kerke deur die staat (Adam 1985:24). Besondere aandag is aan die inrigting en die versiering van die kerke gegee. Ligte, goud en edelgesteentes kry 'n belangrike plek in die kerkgeboue, saam met skilderye en mosaïek wat alles meegehelp het om 'n atmosfeer van verwondering en majesteit te skep (Walker 1997:193). Die altaar, wat vroeër 'n beweeglike tafel vir die nagmaal was, word nou 'n werklike altaar met 'n vaste plek, waarop die "heilige voorwerpe" 'n plek kry. 
In hierdie nuwe kerkgeboue is die erediensruimte ingeklee om die atmosfeer positief te beïnvloed deurdat God se grootheid ook deur die argitektuur na vore kom. Verder kon simbole en rituele nou openlik ingevoer en ten toon gestel word. Die negatiewe was egter dat hierdie grootsheid die intieme karakter van die huiskerk grootliks uitgeskakel het. Groot klem word gelê op die regte uitvoering van al die liturgiese handelinge en daarom word dit al meer net aan die ampte oorgelaat om dit te verrig. Die gemeente word al meer toeskouers vir wie die diens opgevoer word. Teen 1200 het dit selfs praktyk geword vir die priesters om die Mis te vier sonder dat die gemeente teenwoordig is en het die klem verskuif van die gemeenskap van die gemeente na die offer deur die priester gebring (Volz 1997:154).

Die erediens, en veral die optrede van die priester wat die heilige offer bring, word al meer gesien as iets misterieus en ontsagwekkend (Wegman 1985:142). Dit word verkry deur die geleidelike skeiding van die geestelikes en die leke en die klem op die misterieuse, ontsagwekkende en heilige karakter van die priester, wat ook in die seremonies na vore tree. Dit kom verder na vore in die gebruik om sekere gebede stil of sag te sê ("mystikos", "secreta”) (Barnard 1981:183). Hierdie gebede word nou so sterk met die ontsagwekkende misterie geassosieer dat hulle nie deur die gemeente gehoor mag word nie. Die erediens is nie meer die ontmoeting met die ware God in die alledaagse lewe nie, maar word 'n afgesonderde, heilige, misterieuse gebeure in 'n heilige plek wat afgegrens is van waar die gewone mense bymekaar kom. Die mees essensiële aspek van aanbidding, naamlik die ontmoeting tussen God wat praat en die gemeente wat antwoord, is grotendeels verloor (Deddens 1993:22). God het al minder gepraat en was slegs teenwoordig deur die sakramente en dan slegs op 'n misterieuse wyse. Hoewel die misterieuse 'n belangrike element van die atmosfeer is, mag dit nie oorbeklemtoon word nie, veral nie ten koste van verstaanbaarheid en begrip nie.

In die ontwikkeling van die Roomse liturgie is die Skriflesing en prediking algaande verdring deur die altaar (De Klerk 1982:53). Die leerstuk van die transsubstansiasie het die misdiens voortgebring. Waar die eerste Christelike gemeente gepraat het van "die breking van die brood" en die tweede een van die "eucharistie" of danksegging het dit met verloop "sacrificium" of offer geword. Sedert die 5de eeu ontstaan die benaming "mis", afkomstig van die 
wegsendingsroep: “ite, missa est” - "Gaan, julle is gestuur!”. Die viering van die teenwoordigheid van Christus in die erediens is gesoek in die misoffer op die altaar, waarin onder die gedaante van brood en wyn Christus sy liggaam en bloed, deur die bediening van die priester, aan die Vader opoffer. Hierdie aksente het daartoe gelei dat die gemeente al hoe minder aan die Nagmaal deelgeneem het, omdat die gewone lidmaat nie goed genoeg was om aan hierdie groot, dramatiese, ontsagwekkende gebeurtenis deel te neem nie (Volz 1997:153).

Teen die middel van die vierde eeu begin die Voorbedes al meer verdwyn. In die vroeë kerk was dit juis die korporatiewe daad van die hele gemeente. Die gebede verloor hul karakter as gebede van die gemeente en word al meer gebede van die geestelikes (Volz 1997:154). Met die ontwikkeling van die Gregoriaanse repertoire het teen die jaar 600 duidelike beginsels na vore gekom wat die bydraes van die koor en die gemeente geskei het (Rainbow 1972:132). Die koor is veral gebruik om die meer ingewikkelde melodieë uit te voer. Dit het gelei tot die luisterryke polifonie van die vyftiende en sestiende eeue wat gebruik is om atmosfeer tydens die aanbidding te verryk.

\subsection{Gevolgtrekking uit hierdie periode}

Van die vierde eeu na Christus het daar dramatiese veranderinge in die erediens, en in die besonder in die atmosfeer in die erediens, ingetree. Positiewe gevolge was onder andere: Die groot kerke wat ryklik versier is vir 'n visuele skouspel het die atmosfeer van heiligheid besonder versterk. Die omvang en inhoud van die kerkgeboue het die aanbidders met eerbied en ontsag vervul. Die majestueuse koorsang het 'n positiewe invloed op die atmosfeer gehad deurdat die gemeente deur die rykdom, kompleksiteit, kwaliteit en grootsheid meegesleur is. Negatiewe gevolge was onder andere dat God en die ontmoeting met Hom nie meer sentraal gestaan het nie want die erediens het om die priester en sy offerhandelinge gesentreer. 'n Oorbeklemtoning van die misterieuse lei tot 'n negatiewe atmosfeer waaraan die erediensganger nie meer deel het nie, omdat dit wat gebeur nie meer verstaanbaar is nie. Uiteindelik het die erediens 'n magtige menslike vertoning geword in plaas van 'n ontmoeting met die een, ware God. Hoewel die koorsang die atmosfeer positief beïnvloed het, het dit egter ook negatiewe gevolge gehad deurdat die gemeente al minder deelgeneem het. 
Die verval wat in die Rykskerk begin het, word in die Middeleeue voortgesit. Die volgende gevolgtrekkings kan in sake die atmosfeer gemaak word: Deurdat die erediens in Latyn gehou is, het die gelowiges nie die erediens verstaan nie. Hierdie onverstaanbaarheid is versterk deurdat die priester met sy rug na die gemeente gestaan en onhoorbaar sag gepraat het. In plaas van 'n atmosfeer van gelykheid wat deelname aanmoedig, het 'n atmosfeer van onwaardigheid ontstaan waarin die gelowiges nie aan die erediens kon deelneem nie.

\section{REFORMASIE}

Na die vierde eeu het dit wat wesenlik aan die aanbidding was, te wete die ontmoeting tussen God wat praat en die gemeente wat antwoord, in 'n al groter mate verlore gegaan (Deddens 1993:22). Teen die tyd van die Reformasie is die twee partye wat mekaar in die erediens ontmoet, God en die priester. Die gemeente het die liturgiese drama van 'n afstand aanskou (Leuschner 2001:32). Hoewel die Reformasie hoofsaaklik 'n hervorming van teologie was, was dit onafwendbaar dat ' $n$ hervorming van aanbidding daaruit sou voortvloei (Webber 1982:73). Die Reformasie het die gemeente uit haar toeskouerstatus in die erediens weggeneem en haar status herstel as 'n deelnemende party aan die verbond en haar plek in die erediens aan haar teruggegee (Deddens 1993:23). Die oerbeslissing van die Reformasie was 'n liturgiese beslissing: 'n 'nee' vir die offermis (Brienen 1992:56).

\subsection{Die Reformasie se reaksie op die Roomse erediens}

Die mis het die erediens as ' $n$ korporatiewe gebeurtenis van die gemeente laat verskuif tot 'n karakter van geestelike individualisme. In die Reformasie het dit gegaan om God wat in die erediens met sy gemeente 'n sprekende gemeenskap stig en onderhou (Van Rooyen 1983:50). Deur God se spreke deel Hy die heil van sy Seun deur die werk van die Heilige Gees mee. Die gemeente hoor en glo in gehoorsaamheid en antwoord op hierdie heil wat deur Christus toegeëien word. Daar is dus twee brandpunte: God wat spreek en meedeel en die mens wat luister, antwoord en toeëien. Daarom val die klem in die Reformasie veral op die lees en die verkondiging van die Woord en die Bybelse instelling van die sakramente (Wegman 1985:297). Ook word die gebede en die gemeentelike sang as stigtingselemente van koinonia baie sterk deur die reformatore beklemtoon. Dit is alles gemeenskapstigtende elemente binne die 
erediens wat die atmosfeer wesentlik beïnvloed het. Deur klem te lê op deelname, begrip en die sentrale plek van Christus in die erediens is baie gedoen om 'n Bybelse atmosfeer te skep.

Teenoor die priester as bemiddelaar van die heil tussen Christus en die volk het die reformatore aangedui dat die heil in die erediens bemiddel word deur die geloof deur die werking van die Heilige Gees. Alle gelowiges is gelyk - die verskil tussen die ampte en die gemeente is een van funksie en nie van rang nie (McKee 2003:6). Daar is 'n priesterdom van gelowiges wat almal gelyklik aan God behoort en aan Hom aanbidding en lofprysing verskuldig is. Hierdie klemverskuiwing het tot 'n verandering in die doel van aanbidding gelei: waar die Roomse Kerk die doel van aanbidding gesien het om God te behaag en Goddelike guns te verdien, het die Hervormers dit gesien as antwoord op God se geskenk en gehoorsaamheid aan die Woord. Dit het 'n wesentlike verskil in die atmosfeer gemaak, omdat God nou uit dankbaarheid as Verlosser aanbid is, in plaas daarvan dat verlossing verkry word deur offers van tussengangers.

Die Hervormers het gepoog om die eredienste meer opbouend te maak. Daarom het hulle baie klem gelê op die verstaanbaarheid van die erediens deur dit in die taal van die mense te laat plaasvind (White 1993:122). Die aanbidding moes ook korporatief wees en die hele gemeente het nou aan die Nagmaal deelgeneem. Die aanbidders is ook betrek in die lofprysing en aanbidding, in die vorm van sang, wat daartoe gelei het dat die musiek drasties vereenvoudig is (McKee 2003:10).

\subsubsection{Luther se siening van die erediens}

Vir Luther het die Woord sentraal gestaan en moes alles gedoen word om die Woord te laat heers (Webber 1982:75). Daarom moet die prediking in die erediens herstel word. Liturgie is vir Luther diens aan die ware God (Brienen 1992:56) en daarom is Gód in die erediens in die eerste plek aan die werk. ' $n$ Erediens is vir die aanbidder die gebeure waarin deelnemers hulleself aan hierdie God en sy genadewerk oorgee. Die beslissende realiteit van aanbidding is God se dade, wat deur die aanbidders in dankbaarheid en met lofprysing ontvang word (Junghans 1999:320). Luther het van die beginsel uitgegaan dat as die Skrif nie 'n spesifieke praktyk

uitdruklik verwerp nie, is die kerk vry om dit te hou (White 1994:75). Gevolglik het die Lutherse aanbidding baie van die 
seremoniële praktyke van die katolieke aanbidding behou. Luther lê baie klem op die vryheid van die gelowiges en hy ag eenheid belangrik, maar wil geen eenvormigheid hê nie (Barnard 1981:265). Hoewel Luther se geskrifte aanvanklik in Latyn was, het hy gou die noodsaak van verstaanbaarheid besef en later sy geskrifte en liturgieë in die alledaagse Duits van sy tyd geskryf en die erediens in Duits gelei (White 1989:42).

Luther het die prediking weer verhef tot die sentrale deel van Protestantse aanbidding (White 1989:46). Juis in die prediking is Christus teenwoordig. Luther wou nie wegbreek van die mis nie, maar probeer om dit te suiwer en daarom herstel hy die struktuur van Woord- en Nagmaalsdiens soos in die vroeë kerk (Brienen 1992:57). Hy was verder krities teenoor private Misse en het dit self geweier (White 1989:40). Omdat die Woord vir hom sentraal staan en dit gehoor moes word, was hy gekant teen die gebruik van die priesters om die Mis in stilte te vier sonder dat die gemeente kon hoor wat gebeur (Junghans 1999:318).

Vir die atmosfeer in die erediens het dit belangrike implikasies dat Luther die heilsbemiddelende posisie van die Roomse priesters verwerp en aan elkeen weer vrye toegang tot God gegee het en dat hy beklemtoon het dat gelowiges nie maar toeskouers is nie, maar werklike deelnemers aan die erediens (White 1989:41). Luther was 'n liefhebber van sang en musiek en het gou reeds die waarde daarvan vir die erediens besef. Musiek was een van die maniere waarop die gelowiges hulle algemene priesterskap in die erediens kon uitleef (White 1989:41). Hy gee reeds in 1524 sy eerste evangeliese liedboek uit (Brienen 1992:57). Gemeentesang is bedoel om God te eer en die naaste tot voordeel te wees. Luther se gesange het nie gefokus op die sondaar se ellende nie, maar op God se grootheid en het die sangers gelei tot uitbarstings van vreugde (White 1989:43). Luther self het heelwat gesange geskryf waarvan baie op die Psalms gebaseer is (White 1989:47). Uit die samestelling van hierdie liedere blyk dit dat Luther by sowel die liedereskat van die Roomse kerk as by die Duitse volksliedere aangesluit het (Barnard 1981:267).

Luther se klem op die gebruik van die spreektaal in die erediens het die gemeente toegelaat om saam te bid sodat almal mekaar se gebede kon hoor en verstaan en gevolglik kon saambid (White 1989:41-42). Die gebede is so gedoen dat die gemeente kon deelneem deur responsoriese gebede of gebede wat saam gesê of 
gesing is (White 1989:46). Luther het seremoniële klere, beelde en meeste van die Middeleeuse kultus wat teologies neutraal was, toegelaat en dit adiaphora of middelmatige sake genoem (White 1994:75). Hoewel hy dit as middelmatige sake beskou het, is die visuele (kleredrag, beelde, kunswerke, ensovoorts) tog belangrik vir 'n atmosfeer waarin die totale mens betrek word.

\subsubsection{Zwingli se beskouing van die erediens}

Die belangrikste vir Zwingli was die prediking van die Woord op gereelde basis, in die taal van die mense (McKee 2003:12). In die prediking het dit vir hom gegaan om die herontdekking van die goeie nuus, die evangelie - die heilsboodskap in die Skrif. Hy handhaaf die mondigheid van die gelowiges en beklemtoon dat hulle ook wesenlik deel moet hê aan die erediens. Daarom sy besliste klem op die duidelike, hoorbare en verstaanbare wyse waarop alles moes geskied. Hy wou selfs in die erediens by verskillende geleenthede die mans en vrouens laat deelneem by wyse van 'n wisselgesprek (Barnard 1981:283). Die nagmaal is vir Zwingli 'n herinneringsmaal aan die dood van Jesus Christus en 'n lewende geestelike ervaring, met die brood en wyn wat slegs daar is as tekens om die offer van Christus te onthou en nie as instrumente van die genade nie. In sy latere uitsprake en werke aksentueer hy die geestelike teenwoordigheid van Christus by die Nagmaal in 'n toenemende mate. Hy kom tot die oortuiging dat in plaas van die transsubstansiasie van die brood en wyn in die liggaam en bloed van Christus, daar, deur die werking van die Heilige Gees, 'n transsubstansiasie is van die gelowiges om een met die Gees te wees (Van Rooyen 1983:52). Zwingli het musiek uit die kerk verban en in 1523 sang weggeneem en toe, in 1527, die kerkorrels verwoes. Die eredienste is gekenmerk deur stilte en eenvoud, met geen sang of musiek of ander bykomstige aktiwiteite nie (White 1993:137).

In ooreenstemming met sy verstaan van die Tien Gebooie het Zwingli die belangrikheid om alle visuele kunste uit die kerkgebou te verwyder, beklemtoon. Die klem op die gebod oor die "beelde" het daartoe gelei dat die Hervormers die verbod op visuele afbeeldings van God en ander heilige wesens ernstig opgeneem het (McKee 2003:13). Zwingli se kerkgeboue en liturgie was gevolglik baie eenvoudig, gestroop van alles behalwe die prediking van die Woord, die gebede en die hervormde sakramente. Die deelname van die gemeente aan die nagmaal was 'n belangrike korrektief op die kerk in die Middeleeue. 'n Atmosfeer van deelname is 'n wesentlike 
element van die erediens, maar sy siening van die nagmaal bloot as gedagtenismaal en nie as gemeenskap met die lewende Christus nie het ' $n$ negatiewe invloed op die atmosfeer in die erediens. So was die verwydering van die musiek en visuele ook 'n negatiewe ontwikkeling want daardeur het die gemeente se deelname verminder en het die erediens hoofsaaklik 'n intellektuele hoorgebeure geword.

\subsubsection{Calvyn se standpunte oor die erediens}

Die weeklikse samekoms van die gemeente was nie 'n gewone menslike byeenkoms nie - dit was 'n gebeurtenis gevul met Goddelike aktiwiteit, 'n ruimte waarbinne die God-mens-verhouding uitgebeeld en gebou is (Witvliet 2003:146). In die erediens is God nie net die Een tot wie die aanbidding gerig is nie, maar ook die Een wat aktief handelend is. Daarom gaan dit in die erediens nie in die eerste plek om die mens en wat vir hom aangenaam is nie, maar om God en wat Hom behaag (Brienen 1999:47). Daarom verwerp Calvyn alles in die Roomse misliturgie wat met die offergedagte te make het, sowel as alle ingewikkelde, vormlike en nuttelose seremonies. Gemeenskap met God is dus die kern waarom alles draai en hierdie afstemming van die samekoms en al die liturgiese handelinge op die eer van God, het as keersy dat God die erediens wil gebruik tot seën en heil van die deelnemers (Brienen 1987:160). As teoloog van die Skrif het Calvyn die gemeente en die opbou daarvan in die oog gehad en in die erediens moet hierdie opbou tot uitdrukking kom (McKee 2003:23).

Calvyn wil dat die hele erediens en elke element van die erediens onderworpe sal wees aan die Woord van God (Brienen 1999:49). Hierdie uitgangspunt beteken egter nie dat Calvyn in die Bybel 'n vaste liturgiese orde ontdek het nie. Volgens hom is daar nie so iets is nie. Dit gaan vir hom om 'n geestelike gelykvormigheid aan God se openbaring en 'n gelowige onderwerping aan Jesus Christus. Daarby moet rekening gehou word met sowel die huidige situasie, waarin die gebod van God sy neerslag en uitwerking moet vind, as met die huidige gemeente, waarbinne die ontmoeting met God plaasvind (Brienen 1999:49-50). Calvyn meen dat een vorm nie gepas is vir alle eeue nie en dat daarom van beginsels uitgegaan moet word en nie van bepaalde reëls vir en volgorde van elemente in die erediens nie. Daar is slegs drie dinge wat God in sy Woord uitdruklik voorskryf: Sy Woord moet gepreek word; daar moet gesing en gebid word en die sakramente moet bedien word. 
Soos die ander hervormers het Calvyn besondere klem gelê op die prediking as 'n wesentlike en sentrale deel van die erediens (Barnard 1981:333). Die Gees werk in sowel die prediker, as die verkondiger van die Woord, as in die hoorders sodat hulle dit as God se Woord kan herken. Die gepredikte woord is die kleed waarin God na sy gemeente kom. Hy het klem daarop gelê dat die elemente van die erediens duidelik moes wees en nie te moeilik vir die mense om te verstaan nie (Deddens 1993:23). Die gemeente moes by alles in die erediens betrokke wees en daarom moes alles in die erediens hoorbaar en verstaanbaar wees (Beukes 1993:74) en daarom moes die volkstaal in die samekoms van die gemeente gebruik word. Calvyn gaan uit van die reël wat Paulus in 1 Korintiërs 14:40 neerlê: "Alles moet egter gepas en ordelik geskied". Die gelowiges moet met groot ingetoënheid, ware vroomheid en heilige eerbied die liturgie behartig. Dit gaan in die betaamlike reëling van die liturgie nie om ewige wette nie, maar om ordeninge vir die hier en nou (Brienen 1999:56).

Calvyn het die Roomse mis gesien as afgodsdiens, omdat dit volgens hom neerkom op die aanbinding van 'n fisieke entiteit (Witvliet 2003:132). Saam met Zwingli het Calvyn geleer dat Christus se menslike liggaam in die hemel is en nie alomteenwoordig by elke viering nie. Teenoor Zwingli het hy egter geleer dat die nagmaal nie bloot maar net 'n herinneringsmaal is nie. Christus is werklik teenwoordig in die nagmaal, hoewel dit 'n geestelike teenwoordigheid is en nie 'n fisieke nie. Hy het die nagmaal gesien as 'n genademiddel, waar die brood en wyn nie in die liggaam en bloed van Christus getranssubstansieer word nie (McKee 2003:22). Sy klem op die sursum corda is baie belangrik vir die atmosfeer rondom die nagmaalsviering aangesien dit die gelowige in die teenwoordigheid van Christus plaas. Hierdie verstaan van die betekenis en doel van die Nagmaal het daartoe gelei dat Calvyn 'n gereelde, verkieslik weeklikse, viering van die nagmaal voorgestaan het. Daar is vir hom 'n noue band tussen die Woorddiens en die nagmaalsdiens, wat slegs met groot skade gebreek kan word.

Vir Calvyn was gebed sentraal - sy liturgie is selfs "Die Vorm van Gebede" genoem (McKee 2003:19). Om die woorde van gebed en lofprysing in die mond van die gemeente te lê was essensieel en daarom was sang so belangrik. Calvyn was 'n voorstander daarvan dat gekniel word tydens gebede. So ag hy ook die ophef van hande 
tydens gebede as 'n eg Bybelse simboliese gebaar, want dit is die ophef van die hart na bo. Dit druk ook vertroue en 'n brandende begeerte na verhoring uit (McKee 2003:20). Anders as Zwingli lê Calvyn baie klem op gemeentesang. Die oproep vir die sing van Psalms deur die gemeente was een van Calvyn se eerste hervormingsaksies en een waaraan hy sy lewe lank toegewyd was (Witvliet 2003:205). Reeds in 1537 het Calvyn sy eerste Psalmboek, vir die vlugtelinggemeente in Straatsburg, laat verskyn. Die eerste Geneefse uitgawe het in 1542 verskyn en het 39 metriese psalms bevat. Die eerste volledige Psalmboek het eers in 1562, twee jaar voor Calvyn se dood, verskyn.

Die melodieë is spesifiek vir die psalms gekomponeer en kan verbind word met beide die sekulêre chanson liedere van daardie tyd en die Gregoriaanse dreunsang van die Middeleeue (vgl Witvliet 2003:216-219). Die Geneefse melodieë het egter 'n eie karakter wat anders is as beide hierdie musikale style - dit was nòg die wêreldvreemde musiek wat die Gregoriaanse dreunsang geword het, nòg die eenvoudige toe-eiening van sekulêre liedere uit die kroeë. Vir die atmosfeer in die erediens dui dit op die harmoniese wisselwerking wat moet heers, sodat die erediens nie as wêreldvreemd en irrelevant ervaar word nie, maar tog ook anders omdat die enigste lewende God ontmoet word. Waar sang in die Middeleeue hoofsaaklik deur die koor gedoen is, het die hele gemeente, mans, vroue en kinders, in die kerk in Genève gesing. Die kinders was die sangleiers (Witvliet 2003:211). Calvyn het nie begeleiding van die sang deur enige musiekinstrument toegelaat nie (Barnard 1981:324). Vir Calvyn het instrumentele musiek slegs aan die Ou-Testamentiese bedeling behoort. Psalmsing, as die daad van die hele gemeente, het die rol gehad van beide lofprysing en gebed. Die Psalms is nie primêr vir didaktiese redes gesing nie, maar eerder deur die gemeente om God se heerlikheid te loof.

Soos Zwingli het Calvyn die gebruik van die visuele kunste vir godsdienstige doeleindes verwerp op grond van die tweede gebod se verbod op afbeeldings (McKee 2003:20). Tog was hy nie teen alle visuele kunste gekant nie. "Ek is nogtans nie so met die bygeloof behep dat ek sou meen dat ons geen beelde hoegenaamd moet verdra nie. Maar omdat beeldhou en skilder gawes van God is, vereis ek 'n suiwer en grondige gebruik daarvan, sodat die gawes wat die Here tot sy heerlikheid en tot ons seën aan ons gegun het, nie alleen nie deur die misbruik daarvan besoedel word nie maar ook nie tot ons 
verderf omgekeer word nie" (Institusie, I, 11:12). Van al die visuele kunste het Calvyn waarskynlik die meeste aandag aan die argitektuur gegee. Die plek waar die gelowiges bymekaar gekom het om te aanbid moes geskik gewees het vir die doel. Die belangrike was dat almal teenwoordig die Woord van God moes kon hoor en die tafel waar die nagmaal gevier word moes kon sien. Die gereformeerde erediens het hoofsaaklik die ore en stem aangespreek en nie die oë nie: die woord is gesê en gehoor, die gebede en Psalms gesê en gesing.

In die erediens is dit belangrik dat die atmosfeer deelname van die gemeente stimuleer en aanmoedig. Almal is priesters wat lof en aanbidding offer. Die bring van lof impliseer 'n atmosfeer van vreugde. Dit is egter belangrik dat die erediens binne 'n atmosfeer van orde en rustigheid geskied en dit wat gebeur waardig sal wees. Calvyn het begrip gehad vir simboliese handelinge soos die nagmaal en gebedshouding. Die klem op die erediens as 'n getuienis teenoor die wêreld is prysenswaardig. Dit noodsaak egter 'n atmosfeer van begrip van en vriendelikheid en ontvanklikheid teenoor die buitestanders en vreemdelinge. Die totale verwydering van die visuele uit die erediens moet as 'n leemte gesien word en was waarskynlik 'n oorreaksie teen Roomse misbruike. Om die erediens grootliks te beperk tot 'n ouditiewe gebeurtenis is 'n verskraling. Die verwydering van instrumentele musiek is 'n soortgelyke verskraling, juis omdat musiek die menslike emosie sterk aanspreek. Die verwydering van visuele en musikale kuns het die aanspraak op die meer kunssinnige kant van die brein, die regterhemisfeer, verminder. Ongelukkig het dit gepaard gegaan met 'n verlies aan emosionele belewenis, omdat die erediens hoofsaaklik die intellek en denke gestimuleer het.

\subsubsection{Evaluering van die Reformasie}

Die atmosfeer van die erediens het verander van 'n onverstaanbare misterie wat waargeneem word, na 'n verstaanbare werklikheid waaraan deelgeneem word. Tog moet onthou word dat die Reformasie in sy wese 'n reaksiebeweging was, 'n poging om reg te stel wat verkeerd was. In die proses van korrigering het die hervormers gewoonlik te ver in die teenoorgestelde rigting beweeg deur te beklemtoon wat agterweë gebly het en wat oorbeklemtoon is te onderspeel, eerder as om na 'n gebalanseerde situasie te soek (McKee 2003:6). Veral in terme van die kunste (visueel, ouditief), die simboliese en die rituele is dit duidelik te merk. Waar die 
Middeleeuse erediens 'n emosionele skouspel sonder begrip was, het die Hervormers die emosionele belewenis te veel afgeskaal in hulle poging om die intellektuele stimulasie en begrip te herstel. In die tydperk na die Reformasie is hierdie klem op die intellektuele, die rasionele verder verstewig.

\section{RASIONALISME VAN DIE $19^{\mathrm{e}}$ EN $20^{\mathrm{e}}$ EEUE}

Ongelukkig is die gees van die Reformasie baie vinnig deur die ontwikkelende Ortodoksie bedreig. Die rasionalisme, wat die skolastiese metodes van die Protestantse Ortodoksie gebruik het, het die verhouding tussen teologie en die preekstoel bedreig. In 'n poging om hulleself te verdedig teen die Rooms Katolieke Kerk en teen mekaar het die Protestantse kerke rigiede leerstellige posisies ingeneem waarin die Bybel die ondergeskikte rol van verskaffer van bewystekste gespeel het om Lutherse of Calvinistiese of ander Protestantse posisies te regverdig (Rogerson 1985:14). Wainwright (1992:65) stel dit dat "(j)ustifiable though these moves may have been in a Church needing reform, their price was paid in the loss of the sacramental dimension and the growth of didacticism which have characterized Protestant worship."

Die sentrale stelling van die modernisme lê in die woorde van die Franse filosoof René Descartes (1596-1650): Ek dink, daarom is ek - 'cogito ergo sum' (De Koker 1998:2). Descartes se spreuk is tiperend van die twee bene waarop die Modernisme staan. Die een been is die "ek". Die vertrekpunt van hierdie denke is die individu (individualisme), die mens (humanisme), die self (subjektivisme) (Hendriks 1996:493). Descartes se “ek dink” verwys ook na die rede, die logika. Aan die rasionalisme word daar in die volgende eeue besondere waarde geheg omdat die opbloei in die wetenskap en tegnologie, die ontwikkeling wat op sovele terreine plaasgevind het, aan die rasionalisme toegeskryf is. Vir die moderne mens met sy rasionele inslag, sy intellektualisme, sy tegnokratiese lewe en vertroue in die wetenskap het die metafisiese en daarmee God en sy openbaring uit die gesigsveld verdwyn (Vorster 1995:449).

Die eindresultaat van die Modernisme was 'n sekulêre wêreld, 'n wêreld wat in sy normale gang nie met God rekening kon hou nie, nie kon glo nie, en ook nie waardes kon handhaaf nie. Indien die teologie alleen volgens die logika en rede bedryf word, as empiriese feite alleen waarheidskarakter, betroubaarheid het, is daar geen plek vir die misterie nie; openbaring in terme van die nuwe hemel en 
nuwe aarde maak dan ook geen sin nie. Hierdie selfs groter klem op die rasionele het ' $n$ groot invloed op die erediens gehad. Die Bybel is op rasionele wyse gedissekteer totdat uiteindelik net die etiese perspektiewe van die Skrif oorgebly het (Vorster 1995:447). Prediking, en daarmee saam die erediens, het op wye vlak verval in etiese rigtinggewing. Die erediens het al meer 'n intellektuele, rasionele klem verkry met die affektiewe en emosionele wat onderbeklemtoon is, omdat alles verklaarbaar en verstaanbaar moes wees. Dit het daartoe gelei dat die sakramente onderbeklemtoon is. Waar die Hervormers weeklikse nagmaal voorgestaan het en, veral Calvyn, die eenheid van die Woorddiens en nagmaalsdiens beklemtoon het, word die Sondagse erediens uitsluitlik 'n Woorddiens met die preek sentraal. White (1993:159) noem hierdie diens "The Preaching Service" omdat die nagmaal nie meer daarin gevier word nie. Nagmaal word nou vier maal per jaar gevier as deel van hierdie preekdiens, hoewel dit eintlik maar net ingevoeg word en nie meer 'n gelyke gewig dra nie.

Vir die atmosfeer was dit 'n negatiewe ontwikkeling omdat die emosionele en affektiewe elemente grootliks verlore gegaan het. Verder is die mistieke onder waardeer wat ruimte vir die werking van die Heilige Gees ingeperk het. Geloof is gewantrou en gevolglik is 'n ware onmoeting met God bemoeilik.

\section{DIE POSTMODERNISME}

Die Modernisme is gedra deur 'n geloof in die mens se potensiaal om goed te wees, evolusionêr te ontwikkel en 'n utopia op hierdie aarde te skep. Ná die vernietigende oorloë van die begin van die $20^{\mathrm{e}}$ eeu wat almal ontgogel het, is 'n wantroue in die ideale van die Modernisme aan die orde van die dag (Hendriks 1996:498). Die ou waarheid dat die mens in die diepste van sy wese tot niks goeds in staat is nie, word al hoe duideliker besef. Postmodernisme het twee uitstaande kenmerke: Die fokus op die mens en sy voorveronderstellings. Die gevolg daarvan is dat objektiewe waarhede en etiese reëls volgens die postmodernisme nie moontlik is nie (Vorster 1999:105). Daarom word die geldigheid van meer as een moontlike waarheid oor dieselfde aangeleentheid aanvaar. Reg en verkeerd word vervang met geldig en óók geldig. Daar is ' $n$ nuwe belangstelling in die metafisiese en daarom kom die individu se lewe in verhouding met en binne die geheel van die kosmos onder die soeklig. Die bestaan van God en die mens se inherente godsdienssin 
word erken. Spiritualiteit en godsdiens het weer belangrik geword omdat dit erken word as die diepste essensie van menswees.

Omdat die rasionele relatief is, kan die irrasionele (godsdiens en geloof) weer geloofwaardig wees in die arena van menslike handelinge, maar dan moet dit godsdiens wees wat die gevoels- en ervaringsveld van die mens aanspreek. Die verwagting van die postmoderne mens lê nie by die dogmatiese of intellektuele aspek van die erediens nie, maar by dit wat "die hart aanspreek" (Vorster 1996:69). In die lewe van die gelowige verskuif die klem van dit wat hy as gelowige moet doen, na dit wat hy kan ervaar en beleef - hy is primêr ingestel op spiritualiteit. Die postmoderne lewensbeskouing bevorder relativisme, omdat daar nie meer vaste waarhede is nie. Dit impliseer geen vaste volgorde in die erediens nie, maar juis afwisseling. Die postmoderne mens soek juis 'n liturgie waaraan hy aktief kan deelneem.

\section{DIE LITURGIESE BEWEGING VAN DIE $20^{\mathrm{E}}$ EEU}

Davies (1986:314) beskryf die liturgiese beweging as die herontwaking van die kerk. Teen die begin van die $20^{\mathrm{e}}$ eeu kom daar 'n herstel van die liturgie deur die ontdekking van geskrifte uit die tweede eeu (Strydom 1994:256) asook 'n nuwe verstaan van die feit dat liturgie en aanbidding sentraal staan in die lewe en werk van die kerk. Hierdie nuwe verstaan het nuwe dinamiek en verwagtings in die kerke veroorsaak, wat die dryfkrag van die liturgiese beweging geword het. Die beweging het met groot krag deur die kerke beweeg, omdat dit in al die verskillende groot tradisies weerklank gevind het (Fenwick \& Spinks 1995:3).

Die tipiese kenmerke van die liturgiese beweging is (vergelyk De Klerk 1999:313): Nuwe klem op die eenheid tussen die Woorddiens en nagmaalsdiens as die twee groot dele van die erediens; die herontdekking van die Vroeë Kerk as model vir die liturgie (die bedoeling was nie om die liturgie van die Vroeë Kerk te herhaal nie, maar om die beginsels daarvan vir die hede praktyk te maak); die herontdekking van die krag van die Woord in die samekoms; hewige verset teen individualisme; nuwe klem op gemeenskapsbeoefening en gemeentedeelname aan die liturgie; die eietydse aard van die aanbidding is deurslaggewend en kom veral na vore in die klem op verstaanbare taal in woord en lied; die wegbeweeg vanaf uniformiteit na pluraliteit, selfs binne 'n enkele tradisie; besondere klem op simbole en rituele. 
Een van die belangrikste gevolge van die Liturgiese Beweging is die meer gereelde viering van die nagmaal in die kerke (Falconer 2003:145). Daar is 'n herstel van die waardering vir die sakramente; 'n hernieude klem daarop dat die nagmaal nie maar net 'n terugdink aan vorige gebeure is nie, maar werklike anamnese, dit wil sê herinnering aan die verlede, deelname in die hede en voorafskaduwing van die toekoms. Verder is daar nuwe klem op die epiklese, die gebed om verligting deur die Heilige Gees.

\section{SAMEVATTING}

Die volgende beginsels kan uit 'n oorsig oor die geskiedenis van die atmosfeer van die erediens afgelei word:

- In die erediens moet God ontmoet word. Dit beteken dat die atmosfeer sodanig moet wees dat die aanbidder op Hom gerig word en sy teenwoordigheid ervaar. Dit impliseer 'n atmosfeer van heiligheid, 'n atmosfeer wat dit duidelik maak dat die erediens nie maar net ' $n$ menslike byeenkoms is nie, maar 'n ontmoeting met die een, ware God. Hierdie besef moet ook deur die atmosfeer die aanbidder tot eerbied en ontsag bring. Dit word beklemtoon in die begrip 'erediens' diens tot eer van God.

- Die erediens mag nie verval in 'n onverstaanbare, misterieuse handeling nie. Verstaanbaarheid deur almal is van kardinale belang in die erediens.

- Die erediens moet gekenmerk word deur liefde - liefde vir God, liefde vir mekaar en liefde vir die wêreld daar buite. Hierdie liefde vir mekaar mond uit in vriendelikheid en warmte teenoor almal teenwoordig. Die erediens moet so ingerig word dat dit almal uitnooi en intrek en nie intimideer of afstoot nie.

- Die erediens moet gekenmerk word deur vreugde en blydskap - uiteindelik is die erediens 'n fees saam met, vir en weens God.

- Hierdie atmosfeer moet juis die teenwoordiges aanmoedig tot en ruimte skep vir deelname en die gebruik van gawes tot opbou van almal.

- Die atmosfeer in die erediens is nie vas nie, maar kan wissel volgens die kerklike jaar, gebeure en omstandighede in die 
gemeente en die wêreld en selfs binne een erediens volgens die liturgiese handeling waarmee besig is.

- Die atmosfeer word onder andere geskep deur die liturgiese ruimte waarbinne die erediens plaasvind, simbole en rituele, fisieke beweging en gebare, musiek en sang en die gebruik van verskillende sintuie.

\section{Literatuurverwysings}

Adam, A 1985. Grundriß der Liturgie. Freiburg: Herder.

Barnard, A C 1981. Die erediens. Pretoria: NG Kerkboekhandel.

Beukes, M J du P 1993. Erediens I. Pretoria: Kital.

Brienen, T 1987. De liturgie bij Johannes Calvijn: zijn publicaties en zijn visies. Kampen: De Groot Goudriaan.

-, 1992. Oriëntatie in de Liturgie. Zoetermeer: Uitgeverij Boekencentrum.

-, 1999. Calvijn en de kerkdienst. Heerenveen: Uitgeverij Groen.

Burger, C 1995. Gemeentes in transito. Vernuwingsgeleenthede in 'n oorgangstyd. Kaapstad : Lux Verbi.

Cabaniss, A 1989. Pattern in Early Christian Worship. Macon: Mercer.

Calvyn, J 1984. Institusie van die Christelike Godsdiens Boek I. Vertaal deur H W Simpson. Potchefstroom: CJBF.

Cobb, P G 1992. The Architectural Setting of the Liturgy, in Jones C, Wainwright G Yarnold E \& Bradshaw P. The Study of Liturgy. London: SPCK, 528-541.

Davies, J G 1986. A new dictionary of liturgy and worship. London: SCM Press.

Deddens, K 1993. Where Everything Points to Him. Translated by Theodore Plantinga. Neerlandia: Inheritance.

De Klerk, B J 1999. Vaartversnelling vra verdieping van ons liturgie. In die Skriflig 33(3), 311-330.

De Klerk, J J 1982. Liturgiese Grondlyne. Kaapstad: NG Kerkuitgewers.

De Koker, W 1998. Evangelisasieteorie en - praktyk in die lig van die paradigmaverskuiwing van modernisme na postmodernisme. Praktiese teologie in Suid-Afrika 13(1), 1-13.

Falconer, A D 2003. Word, Sacrament, and Communion: New Emphases in Reformed Worship in the Twentieth Century, in Vischer, L (ed.). Christian Worship in Reformed Churches past and present. Grand Rapids: Eerdmans, 142-158.

Fenwick, J \& Spinks, B 1995. Worship in transition. The liturgical movement in the twentieth century. New York: Continuum. 
Hendriks, H J 1996. Modernisme: ten diepste ons identiteit? In die Skriflig 30(4), 489-501.

Hughes, P A 2004. Worship in the Second Century: The Spiritual Dimension. [Beskikbaar op Internet:] http://www.geocities.com/Athens/Crete/6111/ pneumatikos/2century.htm [Datum van gebruik: 3 Julie 2004].

Hurtado, L W 1999. At the Origins of Christian Worship. Grand Rapids, MI: Zondervan.

Junghans, H 1999. Luther on the Reform of Worship. Lutheran Quarterly 13, 315-333.

Leonard, R C 2004. Worship in the Early Church. [Beskikbaar op Internet:] http://www.laudemont.org/a-witec.htm [Datum van gebruik: 3 Julie 2004].

Leuschner, F W 2001. Die erediens as instrument in gemeentebou. MThskripsie, Potchefstroom: PU vir CHO.

McKee, E A 2003. Reformed Worship in the Sixteenth Century. (In: Vischer, L ed.Chritian Worship in Reformed Churches past and present. Grand Rapids: Eerdmans, 3-31.

McKinion, S A 2001. Life and Practice in the Early Church. New York: New York University Press.

Müller, J. 1990. Die erediens as fees. Pretoria : NG Kerkboekhandel.

Patterson, L G 1994. The Worship of the Early Church (to A.D. 500), in Webber, R E (ed.), The Complete Library of Christian Worship. Volume 2, Twenty Centuries of Christian Worship. Nashville, TN: Star Song, 31-43.

Rainbow, B 1972. Choir (Musical), in Davies, J G (ed.). A Dictionary of Liturgy and Worship. London: SCM Press, 131-132.)

Rogerson, J 1985. Beginning Old Testament Study. London: SPCK.

Schoeman, J J 1994. Die aandeel van die gemeente aan die erediens. DDproefskrif, Pretoria: UP.

Skarsaune, O 2002. In the Shadow of the Temple. Jewish Influences on Early Christianity. Downers Grove: InterVarsity Press.

Strydom, W M L 1994. 'n Katoliek-gereformeerde (eucharistiese) diensorde vir die Ned Geref Kerk? Nederduitse Gereformeerde Teologiese Tydskrif 35(2), 256-268.

Van Rooyen, H A 1983. Die Erediens as Koinonia. Skripsie - Nagraadse Diploma in Teologie. Pretoria: UP.

Volz, C A 1997. The Medieval church: from the dawn of the Middle Ages to the eve of the Reformation. Nashville: Abingdon Press.

Vorster, J M 1995. Vernuwing in die prediking in die lig van hedendaagse lewensbeskoulike tendense? In die Skrifli, 29(3), 443-466.

-, 1996. Is die kerk funksioneel? Gedagtes oor gereformeerde kerkvernuwing in 'n postmoderne konteks. Potchefstroom: PTP. 
-, 1999. 'n Waarskynlike bedieningsmilieu vir die GKSA in die dekades na 2000. In die Skriflig 33(1), 99-119.

Vos, C J A \& Pieterse, H J C 1997. Hoe lieflik is u woning. Pretoria: RGN.

Wainwright, G 1992. The Periods of Liturgical History, in Jones, C Wainwright, G, Yarnold, E, Bradshaw, P (eds.). The Study of Liturgy. London: SPCK, 61-67.

Walker, W 1997. A History of the Christian Church. Ediburgh: T \&. T Clark.

Webber, R E 1982. Worship. Old and new. Grand Rapids: Zondervan.

Wegman, H A J 1985. Christian Worship in East and West A Study Guide to Liturgical History. Translated by G.W. Lathrop. New York: Pueblo Publishing.

White, J F 1989. Protestant Worship. Traditions in Transition. Louisville: Westminster.

-, 1993. A brief history of Christian Worship. Nashville: Abingdon.

-, 1994. Lutheran Worship, in Webber, R E (ed.). The Complete Library of Christian Worship. Volume 2, Twenty Centuries of Christian Worship. Nashville, TN: Star Song, 75-76.

Witvliet, J D 2003. Worship seeking understanding. Grand Rapids: Baker. 